\title{
Nuevas tendencias en la novela
}

Si se me pidiera un consejo sobre el mejor desarroilo de la novela en nuestro continente, diría yo a los jóvenes escritores: evitad toda fórmula, por halagüeña que sea. Este consejo no sería sino el producto de la observación de las mejores obras que han aparecido entre nosotros en los últimos veinte años. Azuela y Martín Luis Guzmán concretan el sentido de la revolución mexicana, pero sus continuadores no logran dar mayor prestigio a la materia; Rivera no tiene antecedentes para su Vorágine; Ricardo Güiraldes acierta saliéndose del marco estrecho de la concepción de novela gauchesca; Pedro Prado transforma sus ímpetus líricos en obra de ficción. Cuando el tema se hace acervo común, se empobrece, se limita la imaginación del autor, se cae en el defecto de la repetición infinita. Esto es lo que ha pasado a los jóvenes ecuatorianos con el tema indígena; a los argentinos, anteriores a Güiraldes, con el gauchesco; a los mexicanos, con el de la revolución. Estas observaciones que se me ocurren acerca de la novela, se podrían aplicar también a la poesía lírica de América, cuya pobreza en estos últimos años, gracias a las fórmulas europeas, es verdaderamente desesperante.

E1 tema americano es abundantísimo y se demuestra palpablemente en el afán que existe entre los escritores extranjeros por escribir sobre nuestras cosas. No necesitamos entonces recurrir a fórmulas importadas, ya que entre fondo y forma debe haber una correlación especial, un ritmo propio. Es frecuente 
oír en boca de críticos norteamericanos y europeos opiniones de esta naturaleza, al hablar de nuestros escritores: "no agregan nada a lo que ya conocíamos de España y Francia". Creo quie en estos treinta y nueve años del siglo presente el sentido americanista de nuestra literatura nos ha dado una alta representación en las letras universales y debemos mantener este tono de sinceridad, pero al mismo tiempo se nos impone, como necesidad absoluta, la variedad temática y la diferenciación estilística. Por considerarlos apropiadas para ilustrar estas ideas, hago aquí unos breves comentarios a dos novelas recientemente aparecidas: la primera, Cholos, anuncia el agotamiento de un tema y de una forma; la segunda, La vida inútil de Pito Pérez, señala nuevas posibilidades en el cultivo de la novela hispanoamericana.

Cholos (I) intitula Jorge Icaza su última novela. A1 leer este libro uno termina por creer en aquello de que todo novelista no hace sino una obra, pues entre Huasipungo, En las calles y Cholos, hay sólo ciertas diferencias de detalle. La técnica de las tres novelas es idéntica: diálogo constante, jipíos de los indios, términos escatológicos, abuso de las escenas naturalistas, descarnada realidad, esbozo de caracteres y aglomeración de episodios. Lo mismo puede decirse del contenido: crueldad de gamonales, patrones, jefes políticos; hipocresía y degeneración de los curas, sufrimiento de los indios. La novela podría titularse también Blancos, cholos e indios, porque el autor estudia la vida y la psicología de personajes de estos tres grupos raciales. Cholos es una novela de combate, y en cuanto a las ideas en ella contenidas estamos en perfecto acuerdo con Icaza: estas cosas hay que decirlas, que gritarlas a todos los vientos para que desaparezcan los abusos antes que los amos blancos hagan desaparecer a la raza indígena. Sin embargo, yo creo que Icaza desea hacer obra más completa, y por lo tanto más duradera. No lo ha logrado en la presente novela, que se resiente de precipitación, de flojedad en la forma, de confusión de propósitos. Las lamentaciones infinitas y cansadas de los indios, en vez de intensificar el sentido de tragedia, lo debili-

(1).--Jorge Icaza, Cholos, Quito, 1938, 244 págs. 
tan; ciertos episodios de aberraciones sexuales estarían mejor en un libro de patología. Con todo, la novela interesa por su sentimiento de humanidad, por cierto dinamismo propio de este autor, por la intensidad del color local y porque Icaza es, a pesar de sus taras, un escritor de pura cepa que, en caso de renovarse, nos dará todavía obras fuertes, originales, como aquel Huasipungo, que no ha podido superar. A pesar del descenso que indica Cholos creo que Icaza sigue siendo el novelista ecuatoriano de mayor porvenir.

En La vida inútil de Pito Pére: (2) el novelista mexicano $J$. Rubén Romero continúa la labor emprendida en sus tres novelas anteriores: Apuntes de un lugareño, Desbandada, El pueblo inocente. Redondea Romero una especie de ciclo provinciano, unas anotaciones noveladas a la vida de Michoacán, su estado natal. Los que hemos tenido la fortuna de visitar pueblos como Acámbaro, Morelia, Pátzcuaro, Uruapan, sabenos con qué grado de fidelidad describe Romero las costumbres de las gentes de esas tierras; colonial ambiente en Morelia, lacustre belleza de Pátzcuaro, orgía de flores en Uruajan. La vida inútil de Pito Pérez es una novela picaresca. Pito es el peregrino con alma de poeta, el pícaro moderno en el medio mexicano. Anda por muchos pueblos, sirve de monaguillo, ayudante de boticario, amantuense de juzgado, vendedor de baratijas. Tiene aventuras con doncellas y otras que no lo son tanto, con matones de suburbio, con la policía, y, cansado del amor y del mundo, rapta a la única mujer que le podía hacer feliz, a la Caneca:

"Ahora vivo con ella, muy a gusto; me espera en casa con mucha sumisión, teniendo siempre una copa en la mano; duerme junto de mí, digo mal, vela mi sueño, jamás cierra los ojos en cuyo fondo anidan todas las ternuras".

Cuando un amigo, sorprendido de tanta bondad le pregunta: “¿pero de quién se trata?”, Pito contesta :

(2).--I. Rubén Romero. La vida inútil de Pito Pérez, México, I938, 228 págs. 
"Pues de quién se ha de tratar! Del esqueleto de una mujer, armado cuidadosamente por el médico de Zamora y utilizado por los practicantes del hospital para estudiar anatomía”.

Romero hace derroche de humorismo en esta novela, da auténticos cuadros de vida, y si algunas veces se le pasa la mano en la socarronería, otra se eleva a un estilo poético, como cuando describe el himno de las campanas:

"Tintinea alegremente la campana de Tingiiindín; canta la de Tirindaro; convoca danzas bullangueras la de Paracho; la de Irimbo, como un reloj de paz, da el toque de descanso para los labradores rendidos. Las que llevo aquí, junto a mi pecho, son las campanas de mi tierra, ésta la de la Guanoncha, que canta la alborada en las fiestas grandes; ésta, la de la Hermandad, que dobla por los difuntos, y ésta de plata, pequeñita, representa la de la parroquia, que tantas veces hice vibrar con mis manos entumecidas por el frío, para llamar a misa primera".

Como Cholos, la novela de Romero es genuinamente americana, porque los acontecimientos y las cosas adquieren nuevas proporciones, porque aunque el tema sea antiguo hay en ella un aire distinto, un temblor humano que no habíamos sentido en las obras que venian de Europa.

Arturo Torres-Rioseco. 